\title{
ОБЪЕКТИВНОСТЬ КОМПЕНСАЦИИ МОРАЛЬНОГО ВРЕДА В ГРАЖДАНСКОМ СУДОПРОИЗВОДСТВЕ
}

\section{OBJECTIVITY OF COMPENSATION FOR MORAL DAMAGE IN CIVIL PROCEEDINGS}

M. Krioni

D. Voronin

Summary. The amount of moral damage compensation being sought is currently determined by the judge's inner conviction and taking into account the circumstances of the case. We consider it necessary to exclude the factor of subjectivity and propose a specific formula for calculating compensation for moral damage, taking into account the circumstances that are important in the opinion of the authors, based on the legislative framework of the Russian Federation.

The object of the study is the grounds for the recovery of the amount of compensation for moral damage.

The subject of the study is the derivation of the formula for the amount of compensation for moral damage, based on the legislative framework on its size, taking into account all factors that affect the amount of compensation for moral damage by virtue of the law, as well as according to the authors.

As a result of the study, the factors that affect the amount of compensation for moral damage by virtue of the law were identified, namely -

- the nature and extent of the moral suffering caused to the plaintiff;

- the nature and extent of the physical suffering caused to the plaintiff;

- the degree of the defendant's guilt.

As a result of the study, the factors that influence the amount of compensation for moral damage according to the authors were also identified, namely.

- the nature of the grounds for compensation for moral damage;

- who caused moral damage: an individual or a legal entity.

As a result of the study, a detailed analysis of all the circumstances that affect the amount of compensation, a mathematical formula for calculating the amount of compensation for moral damage in civil proceedings was derived. According to the authors, the factors affecting the amount of compensation for moral damage are exhaustive.

Keywords: moral harm, compensation for moral harm, the amount of compensation, the formula of compensation for moral harm, calculation of the amount of moral harm.

\author{
Криони Мария Валерьевна \\ чОУ ВО «Московский университет им. С.Ю. Buтmе» \\ m.krioni@mail.ru \\ Воронин Дмитрий Борисович \\ ФГБОУ ВО «Омский государственный университет \\ им.Ф.М. Достоевского»
}

Аннотация. Размер взыскиваемой компенсации морального вреда в настоящее время определяется по внутреннему убеждению судьи и с учетом обстоятельств дела. Мы считает необходимым исключить фактор субъективности и предложить конкретную формулу расчета компенсации морального вреда, с учетом обстоятельств, имеющие важное значение по мнению авторов, с опорой на законодательную базу Российской Федерации.

0бъектом исследования выступают основания для возникновения взыскания суммы компенсации морального вреда.

Предметом исследования является выведение формулы размера компенсации морального вреда, опираясь на законодательную базу о ее размерах с учетом всех факторов, которые влияют на размер компенсации морального вреда в силу закона, а также по мнению авторов.

В результате исследования были установлены факторы, которые влияют на размер компенсации морального вреда в силу закона, а именно:

- характер и объем причиненных истцу нравственных страданий;

- характер и объем причиненных истцу физических страданий;

- степень вины ответчика.

В результате исследования были установлены также факторы, которые влияют на размер компенсации морального вреда по мнению авторов, а именно:

- природа возникновения оснований для компенсации морального вреда;

- кем причинен моральный вред: физическим лицом или юридическим.

В результате исследования, подробного анализа всех обстоятельств, которые влияют на размер компенсации, была выведена математическая формула расчета размера компенсации морального вреда в гражданском судопроизводстве. По мнению авторов, факторы, влияющие на размер компенсации морального вреда носят исчерпывающий характер.

Ключевые слова: моральный вред, компенсация морального вреда, размер компенсации, формула компенсации морального вреда, расчет суммы морального вреда. 
B озможность взыскания компенсации морального вреда в гражданском судопроизводстве определяет Гражданский Кодекс Российской Федерации и множество Федеральных Законов России. Приведем некоторые из них: нарушение личных неимущественных прав либо за действия, посягающие на принадлежащие гражданину нематериальные блага (статьи 151-152 Гражданского Кодекса Российской Федерации (часть первая) от 30.11.1994 г. № 51-Ф3; статьи 1099-1101 Гражданского Кодекса Российской Федерации (часть вторая) от 26.01.1996 № 14-Ф3); нарушение тайны завещания (статья 1123 Гражданского Кодекса Российской Федерации (часть третья) от 26.11.2001 № 146-Ф3 (ред. 18.03.2019 г.); дискриминация в сфере труда (статья 3 Трудового Кодекса Российской Федерации от 30.12.2001 N197-Ф3 (ред. от 09.03.2021); незаконное увольнение (перевод на другую работу) работника (статья 394 Трудового Кодекса Российской Федерации от 30.12.2001 N197-Ф3 (ред. от 09.03.2021); нарушение изготовителем (исполнителем, продавцом, уполномоченной организацией или уполномоченным индивидуальным предпринимателем, импортером) прав потребителя (статья 15 Федерального Закона от 07.02.1992 N2300-1 (ред. от 08.12.2020) «O защите прав потребителей»); нарушение прав и интересов в результате распространения ненадлежащей рекламы (статья 38 Федерального закона от 13.03.2006 N38-Ф3 (ред. от 08.12.2020) «О рекламе» (с изм. и доп., вступ. в силу с 01.01.2021); осуществление обработки персональных данных с нарушением требований, а также нарушение прав и свобод субъекта персональных данных (статья 17 Федерального Закона от 27.07.2006 № 152-Ф3 «О персональных данных»); невыполнение условий договора о реализации туристского продукта туроператором или турагентом (статья 6 Федерального Закона от 24.11.1996 № 132-Ф3 «Об основах туристической деятельности в Российской Федерации»)'

Все указанные нормы содержат возможность компенсации морального вреда, однако, о конкретном размере данной компенсации ни одно из вышеупомянутого положения речь не ведет.

На сегодняшний день, законодатель определил размер компенсации морального вреда субъективно, и даже абстрактно. Всё что он [законодатель] предложил, это список факторов, влияющих на размер компенсации, с условием разумности и справедливости².

\footnotetext{
' Данный перечень не является исчерпывающим, и носит ознакомительный характер

2 части 1, 2 статьи 1101 Гражданского Кодекса Российской Федерации; Статья 151 Гражданского Кодекса Российской Федерации (часть первая) от 30.11.1994 г. № 51-Ф3; Статья 237 Трудового Кодекса Российской Федерации от 30.12.2001 N197-Ф3 (ред. от 09.03.2021); абзац 9 статьи 394 Трудового Кодекса Российской Федерации от 30.12.2001 N197-Ф3 (ред.
}

Таким образом, уникальность исследования заключается в новом способе расчета размера компенсации морального вреда в гражданском судопроизводстве, который не будет зависеть от внутреннего убеждения судьи, тем самым исключить субъективность.

Актуальность данной темы обусловлено тем, что, как можно заметить, взыскание морального вреда регламентировано множественными положениями Законов Российской Федерацией, которые регулируют различного рода гражданско-правовых отношений, тем самым обеспечивая возмещение морального вреда в разносторонних общественных отношениях.

Как мы видим однозначной суммы или способа расчета компенсации морального вреда в Российском законодательстве нет, но как можно заметить, есть определенные критерии, которые учитываются при определении размера компенсации морального вреда.

Для выведения формулы компенсации морального вреда рассмотрим данные критерии подробнее.

Итак, при рассмотрении в суде вопроса о размере компенсации морального вреда Верховный суд Российской Федерации и Гражданский Кодекс Российской Федерации определяют важными следующие обстоятельства:

- характер и объем причиненных истцу нравственных страданий;

- характер и объем причиненных истцу физических страданий;

- степень вины ответчика;

- иные заслуживающие внимания обстоятельств.

Характер и объем причиненных истцу нравственных страданий. «Словарь русского языка» Ожегова С.И. определяет страдания как физическая или нравственная боль, мучение.

По своей сути нравственные страдания - это страдания, которые человек переживает внутри себя страдания души. К ним могут относиться утрата родного человека (скорбь); невозможность продолжать активную деятельность (подавленность, страх); чувства, связанные с потерей работы; чувства стыда или страха, связанные с раскрытием семейной или врачебной тайн; распространение не соответствующих действительности сведений, порочащих честь, достоинство или деловую репутацию гражданина; временное ограничение или лишение каких-либо прав; чувства,

от 09.03.2021); пункт 8 Постановления Пленума Верховного Суда РФ от 20.12.1994 N10 (ред. от 06.02.2007) «Некоторые вопросы применения законодательства о компенсации морального вреда». 
связанные с необходимостью делать (создавать) чтото заново (найти новую работу, необходимость делать операцию, необходимо купить новую машину).

Данное определение наводит нас на очевидный вопрос: как можно оценить страдания души и возможно ли это? На наш взгляд, данная категория не подается какому-либо обозначению. Истец, заявляя о том, что перенес нравственные страдания в связи, например, со смертью (утратой) матери никак не способен предоставить в суд какие-либо доказательства. Отношения между родителем и ребенком могут быть разными. Возможно десятилетиями не общаться и иметь самые скудные отношения. Но даже если в суд придут свидетели и факт отсутствия теплых отношений будет установлен, неужели это будет означать, что смерть родного по крови человека никак не повлияло на душу Истца. Напротив, душа должна испытывать терзания, мучения. И суд должен априори предполагать нравственные страдания у истца, даже если на самом деле ему безразлична смерть близкого.

Данная политика пропагандирует любовь к родному (близкому) человеку, и к людям в целом, что является фундаментом построения цивилизованного общества.

Верховный суд Российской Федерации при наступлении определенного случая предполагает наличие нравственных страданий: «При этом суду следует иметь в виду, что, поскольку потерпевший в связи с причинением вреда его здоровью во всех случаях испытывает физические или нравственные страдания, факт причинения ему морального вреда предполагается. Установлению в данном случае подлежит лишь размер компенсации морального вреда».

Таким образом, считаем, что установив наличие оснований для взыскания компенсации морального вреда суд должен во всех случаях предполагать наличие нравственных страданий, а не только в случаях причинения вреда здоровью Истцу.

Теперь необходим показатель, который будет определять нравственные страдания. Данный показатель:

- должен быть постоянной величиной;

- должен балансировать интересы сторон;

- не должен зависеть от заработной платы, так как в противном случае у ответчика будет заинтересованность в меньшем заработке или вовсе в его отсутствии;

- не должен подчеркивать классовую принадлежность истца, но обеспечить равновесие для различного финансового положения истцов по гражданским делам о взыскании компенсации морального вреда.
Согласно дела «Максимов против Российской Федерации» Европейского Суда по правам человека суд акцентировал внимание на то, что национальные суды при назначении компенсации морального вреда, должны присуждать такую сумму, которая будет оцениваться в соответствии с собственной правовой системой, традициями и уровнем жизни в данной стране.

Таким образом, предлагаем взять для обозначения нравственных страданий - МРОТ.

Данная величина определяется Правительством Российской Федерации, а также субъектами Российской Федерации.

По нашему мнению, показатель МРОТ будет обеспечивать баланс интересов сторон. Соответственно в расчет будет браться МРОТ, установленный в субъекте, где зарегистрирован ответчик. Так как по общему правилу исковое заявление подается в суд по месту жительства ответчика. В тех случаях, когда законодатель дает возможность выбора суда истцу не изменят данное правило. В противном случае может усматриваться недобросовестность со стороны истца, подавая исковое заявление в субъекте, где МРОТ установлен в большем размере.

Характер и объем причиненных истцу физических страданий. Физическое страдание - это физический (физиологический) дискомфорт, негативные изменения в организме человека. Например, боль; головокружение; депрессия; любое психологическое (либо психиатрическое) заболевание; паранойя; физическая боль, связанная с причиненным увечьем, иным повреждением здоровья и т.д. Как мы видим, наличие физических страданий предполагает нравственные, однако, наличие нравственных совсем не порождают физические страдания.

Следует закономерный вопрос: каким образом рассчитать физические страдания? Определить шкалу или разработать таблицу заболеваний недугов не предоставляется возможным. Во-первых, заболеваний множество, и определить их все в гигантской таблице - физически невозможно и слишком громоздко. Во-вторых, рассчитать шкалу, по которой одни заболевания будут стоять выше других просто неосуществимо, а оснований, по которым, например, депрессия будет стоять выше паранойи (или наоборот) нет. Поэтому, мы считаем, что для расчета размера компенсации морального вреда достаточен сам факт причинения физического дискомфорта.

Например, поход к специалисту (консультация хирурга или сеанс у психолога). Здесь не важно это еди- 
ничный поход или это курс. Мы не будем считать каждый поход к одному и тому же специалисту, в противном случае имеет место быть недобросовестности истца. Поэтому наличие в гражданском деле доказательств о факте (необходимости) посещения специалиста - должно расцениваться как единое физическое страдание, или, например, после сеансов у психолога, специалист поставил определенный диагноз - одно физическое страдание за сеанс, второе физическое страдание за диагноз, и третье физическое страдание за лечение, если доказательства такового будет представлены в суд.

Как мы уже сделали вывод о том, что при физических страданиях нравственные предполагаются, то формула начинает приобретать следующий вид:

$$
\text { MPOT1 + (МРОT2 * a), где: }
$$

МРОТ1 - нравственные страдания, которые предполагаются вне зависимости от физических. Данный показатель всегда имеет место быть в случае установление судом оснований для взыскания компенсации морального вреда.

МРОТ2 - нравственные страдания, которые предполагаются в связи с физическими страданиями. Данный показатель имеет место быть, когда установлен факт причинения физических страданий.

а - физические страдания, если физические страдания отсутствуют, то ставится показатель 0.

Степень вины ответчика мы рассмотрим чуть позже, дабы не нарушить логический ход нашей формулы.

Иные заслуживающие внимания обстоятельств. Мы не представляем, что именно под словом «иные» подразумевает Верховный суд Российской Федерации, но предлагаем под «иными обстоятельствами» иметь в виду еще два дополнительных обстоятельств, которые необходимые для нашей формулы.

1. Предмет морального вреда (природа возникновения оснований для компенсации морального вреда):

А) если гражданину причинен моральный вред действиями (бездействиями), нарушающими его личные неимущественные права (право на пользование своим именем, право авторства и другие неимущественные права в соответствии с законами об охране прав на результаты интеллектуальной деятельности);

Б) если гражданину причинен моральный вред действиями (бездействиями), посягающими на принадлежащие гражданину нематериальные блага (жизнь, здоровье, достоинство личности, деловая репутация, неприкосновенность частной жизни, личная и семейная тайна и т.п.);

В) если гражданину причинен моральный вред действиями (бездействиями), нарушающими имущественные права гражданина.

Когда мы разделили предмет, то теперь возможно и определить их иерархию. Предполагаем, что с нашей иерархией вы будете полностью согласны.

Итак, в связи с тем, что жизнь и здоровье бесценны, то моральный вред, причиненный нематериальным благам истцу должны возглавить нашу иерархию, а соответственно присудить ей больше баллов.

Второе место несомненно займут личные неимущественные права. И третье - взыскание морального вреда, причиненного имуществу истца.

Таким образом, распределяем баллы следующим образом:

Б) если гражданину причинен моральный вред действиями (бездействиями), посягающими на принадлежащие гражданину нематериальные блага (жизнь, здоровье, достоинство личности, деловая репутация, неприкосновенность частной жизни, личная и семейная тайна и т.п.) - 3 .

А) если гражданину причинен моральный вред действиями (бездействиями), нарушающими его личные неимущественные права (право на пользование своим именем, право авторства и другие неимущественные права в соответствии с законами об охране прав на результаты интеллектуальной деятельности) - 2 .

В) если гражданину причинен моральный вред действиями (бездействиями), нарушающими имущественные права гражданина - 1 .

Обозначит данный показатель - b.

Необходимо учесть в данном показателе тот факт, что при причинении гражданину морального вреда действиями (бездействиями) нарушающие его имущественные права, то полученная сумма компенсации морального вреда делится на количество собственников данного имущества. В других же категориях, компенсация морального вреда определяется для каждого истца, в зависимости от физических и нравственных страданиях понесенные каждым Истцом в отдельности.

2. Кем причинен моральный вред: физическим лицом или юридическим.

Разумеется, когда ответчиком по гражданскому делу выступает юридическое лицо, само юридическое 
лицо не причиняет нравственные или физические страдания. Оно [юридическое лицо] может не соблюсти требования технической, пожарной безопасности, в результате которых был причинен вред истцу. Оно [юридическое лицо] может недоплатить заработную плату, премии и иные выплаты, причитающиеся истцу, в результате данных действий которого у истца возникает право требования морального вреда.

Таким образом, юридическое лицо не может прямо причинить нравственные или физические страдания, оно может нарушить требования, закон и иные нормативно правовые акты, в результате которых произошло причинения страданий истцу. Поэтому балл за причинения морального вреда юридическим лицом меньше, чем физическим.

Распределяем баллы следующим образом:

- моральный вред, причиненный физическим лицом - 2 .

- моральный вред, причиненный юридическим лицом - 1 .

\section{Обозначит данный показатель - с.}

На наш взгляд, данные обстоятельства носят исчерпывающий характер, для определения формулы компенсации морального вреда. Каждый из показателей необходим и важен для определения размера данной компенсации.

Формула приобретает следующий вид:

$$
(\text { MPOT1 + }(\text { MPOT2 *a) }) *(b+c),
$$

Степень вины ответчика. Оценка степени вины в гражданском судопроизводстве имеет две формы: «вина есть» и «вне зависимости от вины». В противном случае, если имеет место быть как непреодолимая сила, или вовсе отсутствие вины, оснований для взыскания морального вреда отсутствует. Но в Гражданском Кодексе Российской Федерации степень вины классифицируется, как «грубая неосторожность», «необходимая оборона», «крайняя необходимость».

Автор считает, что в данную группу необходимо добавить случаи, когда можно полагать, что ответчик своими действиями желал уменьшить причиненный вред (например, при причинении вреда здоровью ответчик покупал медикаменты, оплачивал лечение, то есть любая материальная помощь), а также случаи, когда ответчик желает урегулировать спор в досудебном порядке (например, при спорах с застройщиком, ответчик старается своими силами исправить строительные дефекты, то есть идет на примирительные меры, стараясь исправить положение).
В последнем случае необходимо поставить дополнительное условия, для того чтобы у ответчика не было корысти уменьшить размер компенсации морального вреда искусственно. При желании урегулировать спор в досудебном порядке, следует учитывать дополнительно желание ответчика на мировое соглашение.

При таких смягчающих обстоятельствах, несправедливо будет применять формулу без характеристики ответчика. Его действия и поведения в споре должно учитываться при вынесении решения суда.

Мы полагаем, что уместно будет при наличии названных выше обстоятельствах применить степень -1 к значению, где учитывается сам ответчик и основание. То есть скобка, где определяется лицо причинившее вред, и природа возникновения основания для взыскания компенсации морального вреда.

Таким образом, чем более значим предмет возникновения оснований для компенсации морального вреда, тем меньше из формулы вычитается сумма так называемого «смягчающего обстоятельства», что и должно учитываться как степень.

Резюмируя, формула приобретает окончательный вид:

$\left(\right.$ МРОT1 + $($ МРОT2 * a) $) *\left((b+c)-(b+c)^{-1}\right)$, где:

MPOT1 - нравственные страдания, которые предполагаются вне зависимости от физических. Данный показатель всегда имеет место быть в случае установление судом оснований для взыскания компенсации морального вреда.

МРОТ2 - нравственные страдания, которые предполагаются в связи с физическими страданиями. Данный показатель имеет место быть, когда установлен факт причинения физических страданий.

а - физические страдания, если физические страдания отсутствуют, то ставится показатель 0.

b - природа возникновения оснований для компенсации морального вреда:

- если гражданину причинен моральный вред действиями (бездействиями), посягающими на принадлежащие гражданину нематериальные блага (жизнь, здоровье, достоинство личности, деловая репутация, неприкосновенность частной жизни, личная и семейная тайна и т.п.) - 3 балла.

- если гражданину причинен моральный вред действиями (бездействиями), нарушающими его личные неимущественные права (право на пользование своим именем, право авторства и другие неимущественные права в соответствии с зако- 
нами об охране прав на результаты интеллектуальной деятельности) - 2 балла.

- если гражданину причинен моральный вред действиями (бездействиями), нарушающими имущественные права гражданина - 1 балл.

c - кем причинен моральный вред:

- моральный вред, причиненный физическим лицом - 2 балла.

- моральный вред, причиненный юридическим лицом - 1 балл.

- степень применяется, при наличие хотя бы одного условия:

в вред был причинен в связи с грубой неосторожностью;

в вред был причинен в условиях крайней необходимости;

- вред был причинен в условиях необходимой обороны;

- ответчик своими действиями желал уменьшить причиненный вред;

- ответчик желал урегулировать спор в досудебном порядке и идет на мировое соглашение, в остальных случаях, степень не применяется, не ставится, и не учитывается.

Если степень не применяется, то формула сокращается до следующего вида:

$$
(\text { MPOT1 + (MPOT2 * a) }) *(b+c)
$$

Теперь, когда формула приобрела окончательный вид, самое время проверить ее на практике.

Итак, Б. обратился в суд с исковым заявлением к ЮРИДИЧЕСКОМУ ЛИЦУ об устранении строительных недостатков в жилом помещении, взыскании ущерба, причиненного в результате залива квартиры, неустойки, компенсации морального вреда, штрафа. Суд признал требования истца, основанные на законе и удовлетворил исковые требования частично. Была взыскана компенсация морального вреда в размере 20000 рублей.

Согласно материалам дела и решению суда, физические страдания письменными доказательствами не подкрепляются. ЮРИДИЧЕСКОЕ ЛИЦО зарегистрировано в Ханты-Мансийском автономном округе - Югре.

Как видим из входящих данных вред причинен имуществу гражданина, показатель $b=1$. Моральный вред причинен юридическим лицом, показатель $\mathrm{c}=1$.

Путем математического сложения, формула выглядит так:
$(16472$ рублей $+(16472$ рублей * 0)) * $(1+1)=$ 32944 рублей.

Аналогичное дело, в аналогичный период:

ш1 и ш2 обратились в суд с исковым заявлением к ответчику ЮРИДИЧЕСКОМУ ЛИЦУ о защите прав потребителя по договору купли-продажи жилого помещения, взыскания морального вреда. Суд признал требования истцов, основанные на законе и удовлетворил исковые требования частично. Была взыскана компенсация морального вреда в размере 40000 рублей (по 20000 рублей в пользу каждого).

Согласно материалам дела и решению суда, физические страдания письменными доказательствами не подкрепляются. ЮРИДИЧЕСКОЕ ЛИЦО зарегистрировано в Ханты-Мансийском автономном округе Югре.

Как видим из входящих данных вред причинен имуществу граждан, показатель $\mathrm{b}=1$. Моральный вред причинен юридическим лицом, показатель $\mathrm{c}=1$.

Формула не поменяла свое значение. Получаем 32944 рублей: 2 (количество истцов) = 16472 рублей в пользу каждого истца.

Допустим, что ответчик в данном деле желал урегулировать спор своими силами, предлагал мировое соглашение и всячески пытался договориться, тогда сумма компенсации морального вреда составила бы:

$(16472$ рублей $+(16472$ рублей * 0)) * $((1+1)-(1+$ $\left.1)^{-1}\right)=24708$ рублей. Данная сумма делится на всех собственниках, так как причиненный вред основывается на недостатках имущества. 24708 рублей - это компенсация морального вреда на одно имущество, что составляет в конкретном случае 12354 рублей в пользу каждого истца.

Такая большая разница естественна. Так ответчикам выгодно проявлять свою заботу, милосердие и другие положительные действия в отношении истца. Нельзя приравнивать суммой компенсации ответчиков, который идет на диалог и тот, который скрывается, или всячески игнорирует свои обязанности. В нашем случае сумма разницы составила 8236 рублей.

Далее примеры, не содержат расчеты, в которых учитывается степень вины, так как в решениях судов те сведения, которые необходимы, не отражены.

Что касается гражданских дел о компенсации морального вреда, причиненного преступлением: 
Х. обратился в суд с иском к К. о компенсации морального вреда, причиненного преступлением. Ответчик был признан виновным в совершении преступления п. «В» ч. 2 ст. 115 УК РФ. В результате преступления истцу было нанесено огнестрельное ранение правого бедра. Суд признал требования истца, основанные на законе и удовлетворил исковые требования частично. Была взыскана компенсация морального вреда в размере 100000 рублей.

Согласно материалам дела и решению суда, К. произвел три выстрела в Х., в результате которых два из них попали в правое бедро. Х. потребовалось хирургическое вмешательство. Х. необходимо было посещать медицинские учреждения с целью делать перевязки, и приобретать медицинские препараты. К. зарегистрирован в Красноярском крае. В подтверждения указанных фактов суду были предоставлены доказательства.

Как видим из входящих данных вред причинен здоровью гражданина, показатель $b=3$. Моральный вред причинен физическим лицом, показатель с $=2$.

Физические страдания: (1 - за факт повреждения тела (две пути в бедро), причинение легкого вреда здоровью; 1 - необходимое хирургическое вмешательство; 1 - необходимые посещения в медицинские учреждения для перевязки; 1 - необходимость дальнейшего лечения (медицинские препараты). Итого коэффициент $\mathrm{a}=4$.

$(13321$ рублей $+(13321$ рублей * 4))*(3 + 2) = 333025 рублей.

3. обратился в суд с иском к П. о компенсации морального вреда, причиненного преступлением. Ответчик был признан виновным в совершении преступления ч. 2 ст. 264 УК РФ. В результате гибели близкого человека Истец обосновано обратился в суд за компенсацией морального вреда. Суд признал требования истца, основанные на законе и удовлетворил исковые требования частично. Была взыскана компенсация морального вреда в размере 150000 рублей. Согласно материалам дела и решению суда, Ответчик имеет регистрацию г. Ханты-Мансийска. Доказательств о наличие физических страданий нет.

Как видим из входящих данных вред причинен в результате действий, посягающие на принадлежащие гражданину нематериальные блага - показатель $b=3$. Моральный вред причинен физическим лицом, показатель с $=2$. Нравственные страдания по нашей формуле предполагаются.

$(17544$ рублей $+(17544$ рублей *0) $) *(3+2)=$ 87720 рублей.

Таким образом, подводя итог всему вышесказанному, данная формула значительно облегчит дилемму судей о назначении суммы компенсации морального вреда. Тем самым, вытеснив субъективность в решениях судов. Как мы видим из примеров разница в взысканной сумме и в суммах, которые мы предлагаем, не является глобальной. Но наши суммы носят объективный характер. В решениях суда о взыскании компенсации морального вреда в размере 100000 рублей, не ясно почему суд посчитал необходимым взыскать именно эту сумму, а не, предположим, 99000 рублей, или 101000 рублей. Мы предлагаем внести в вопрос компенсации морального вреда ясность, тем самым провести грань между 99000 рублей и 101000 рублей.

На наш взгляд, многие решение о взыскании компенсации подлежат обжалованию по исключительному основанию несогласия той или иной стороной, причиной которой является «несоразмерность». Использование формулы исключит огромный поток «не обоснованных» жалоб, а также побуждения истца к обогащению. Регламентированность данного вопроса позволит избежать взыскание не мотивированных крупных сумм, и наоборот, что в некотором смысле облегчит и исполнительное производство.

\section{ЛИТЕРАТУРА}

1. Конституция Российской Федерации (принята всенародным голосованием 12.12.1993 с изменениями, одобренными в ходе общероссийского голосования 01.07.2020) [Электронный ресурc].— URL: http://www.consultant.ru

2. Гражданский кодекс Российской Федерации (часть первая) от 30.11.1994 № 51-Ф3 с изм. и доп. от 09.03.2021 [Электронный ресурс].— URL: http:// www.consultant.ru

3. Гражданский кодекс Российской Федерации (часть вторая) от 26.01.1996 № 14-Ф3 с изм. и доп. от 09.03.2021 [Электронный ресурс].— URL: http:// www.consultant.ru

4. Гражданский кодекс Российской Федерации (часть третья) от 26.11.2001 № 146-Ф3 с изм. и доп. от 18.03.2019 [Электронный ресурс].— URL: http:// www.consultant.ru

5. Трудовой кодекс Российской Федерации от 30.12.2001 № 197-ФЗ с изм. и доп. от 09.03.2021 [Электронный ресурс].— URL: http://www.consultant.ru

6. О защите прав потребителей: Федеральный закон от 07.02.1992 № 2300-1 (с изм. и доп.) [Электронный ресypc]. — URL: http://www.consultant.ru 
7. 0 персональных данных: Федеральный закон от 27.07.2006 № 152-Ф3 (с изм. и доп.) [Электронный ресурс].— URL: http://www.consultant.ru

8. 0 рекламе: Федеральный закон от 13.03.2006 N38-Ф3 (с изм. и доп.) [Электронный ресурс]. — URL: http://www.consultant.ru

9. Об основах туристической деятельности в Российской Федерации: Федеральный закон от 24.11.1996 № 132-Ф3 (с изм. и доп.) [Электронный ресурc].— URL: http://www.consultant.ru

10. Постановление Пленума Верховного Суда РФ от 20.12.1994 N10 (ред. от 06.02.2007) «Некоторые вопросы применения законодательства о компенсации морального вреда» [Электронный ресурс].— URL: http://www.consultant.ru

11. Постановления Пленума Верховного Суда РФ от 26.01.2010 N1 «0 применении судами гражданского законодательства, регулирующего отношения по обязательствам вследствие причинения вреда жизни или здоровью гражданина» [Электронный ресурc].— URL: http://www.consultant.ru

12. Постановление Правительства Красноярского края от 14 апреля 2020 года № 230-п «06 установлении величины прожиточного минимума на душу населения и по основным социально-демографическим группам населения Красноярского края за I квартал 2020 года» [Электронный ресурс].— URL: https://rg.ru

13. Постановление Правительства Ханты-Мансийского автономного округа — Югры от 24.05.2020 г. № 152-п «0б установлении величины прожиточного минимума на душу населения и по основным социально-демографическим группам населения в Ханты-Мансийском автономном округе — Югре за I квартал 2020 года» [Электронный ресурc].— URL: https://rg.ru

14. Постановление Правительства Ханты-Мансийского автономного округа — Югры от 30 октября 2020 года № 481 -п «06 установлении величины прожиточного минимума на душу населения и по основным социально-демографическим группам населения в Ханты-Мансийском автономном округе — Югре за III квартал 2020 года» [Электронный ресурс].— URL: https://rg.ru

15. Решение Свердловского районного суда г. Красноярска от 13.07.2020 г. [Электронный ресурс].— URL: http://sverdl.krk.sudrf.ru

16. Решение Ханты-Мансийского районного суда Ханты-Мансийского автономного округа — Югры от 07.07.2020 г. [Электронный ресурс]. — URL: http:// hmray.hmao.sudrf.ru

17. Решение Ханты-Мансийского районного суда Ханты-Мансийского автономного округа — Югры от 15.07 .2020 г. [Электронный ресурс].— URL: http:// hmray.hmao.sudrf.ru

18. Решение Ханты-Мансийского районного суда Ханты-Мансийского автономного округа — Югры от 14.12 .2020 г. [Электронный ресурс]. — URL: http:// hmray.hmao.sudrf.ru

○ Криони Мария Валерьевна (m.krioni@mail.ru ), Воронин Дмитрий Борисович.

Журнал «Современная наука: актуальные проблемы теории и практики»

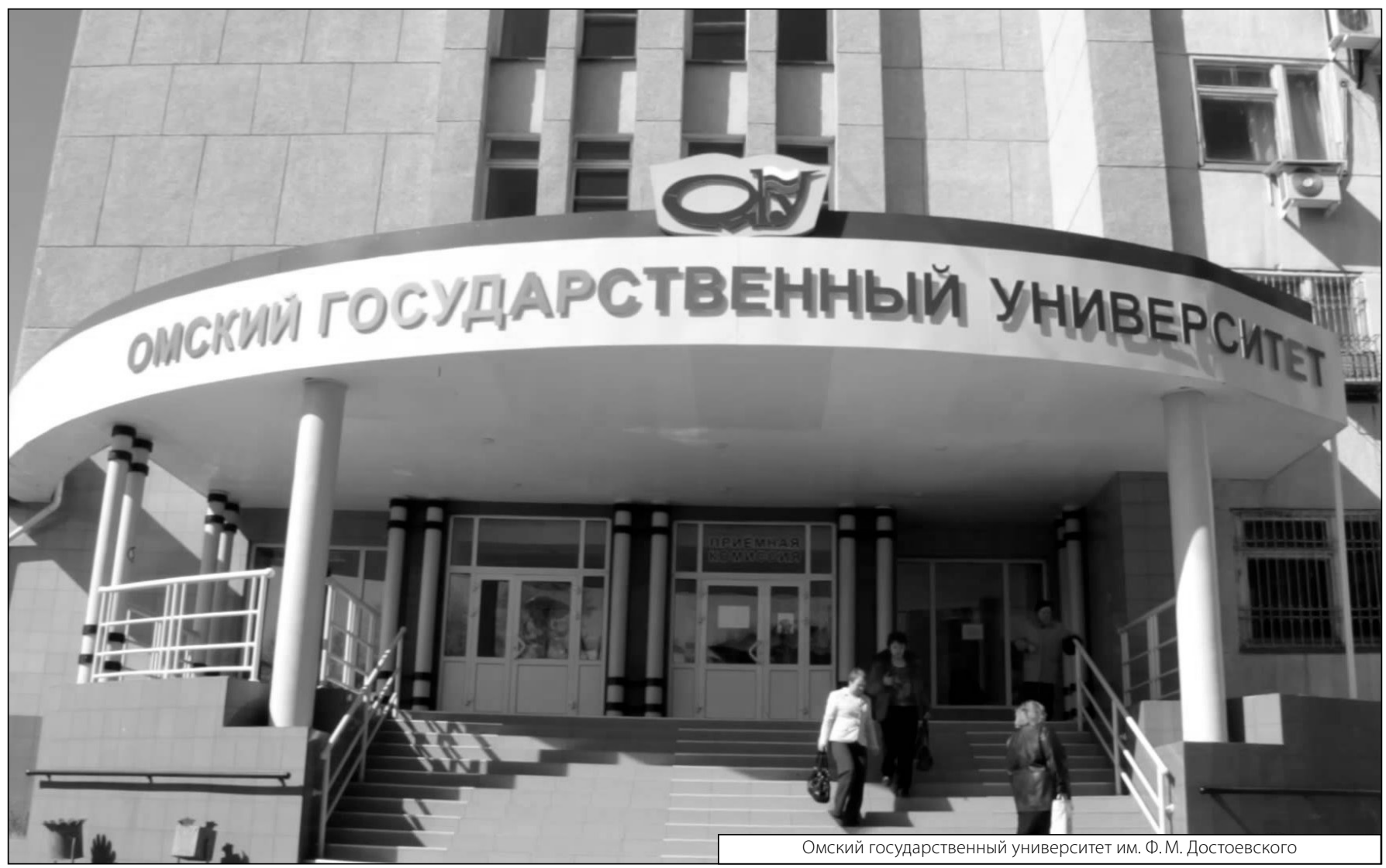

